\title{
Risk factors for necrotic cholecystitis during the COVID-19 pandemic: the ChoCO-WSES prospective collaborative study's experience
}

Belinda de Simone ${ }^{1}$ (D), Fausto Catena ${ }^{2}$ (D), Salomone Di Saverio 3 (D), Massimo Sartelli ${ }^{4}(\mathrm{D})$, Fikri M. Abu-Zidan ${ }^{5}$ (D), Mauro Podda (D), Walter L Biffl ${ }^{7}$ (D), Luca Ansaloni ${ }^{8}$ (D), Federico Coccolini ${ }^{9}$ (D), Ernest E Moore ${ }^{10}$ (D), Yoram Kluger ${ }^{11}$ (D), Carlos Augusto Gomes ${ }^{12}$ (D), Ferdinando Agresta ${ }^{13}$ (D), Elie Chouillard ${ }^{1}$ (D)

\footnotetext{
1 Department of Emergency and Metabolic Minimally Invasive Surgery, Poissy/Saint Germain en Laye Hospitals, France

2 Department of Emergency and Trauma Surgey, Bufalini Trauma Center, Cesena, Italy

${ }^{3}$ Department of General Surgery, Saint Mary of the Rescue, San Benedetto del Tronto, Italy

${ }^{4}$ Unit of General Surgery, Macerata Hospital, Macerata, Italy

${ }^{5}$ Department of Surgery, College of Medicine and Health Sciences, UAE University, Al-Ain, United Arab Emirates

${ }^{6}$ Department of Surgery, Unit of General Surgery, University Hospital of Cagliari, Cagliari, Italy

7 Department of Emergency and Trauma Surgery, Scripps Memorial Hospital, La Jolla-California, United States

${ }^{8}$ Department of General Surgery, University Hospital of Pavia, Pavia, Italy

${ }^{9}$ Department of General Surgery, University Hospital of Pisa, Pisa, Italy

${ }^{10}$ Ernest E Moore Shock Trauma Center at Denver Health Medical, United States

${ }^{11}$ Division of Surgery, Rambam Health Care Campus, Haifa, Israel

${ }^{12}$ Department of Surgery, University Hospital, Juiz da Fora, Brazil

${ }^{13}$ Department of General Surgery, Adria Hospital, Adria, Italy
}

\begin{abstract}
Objective: During the COVID-19 pandemic, several studies have reported a decrease in in the admission surgical patients and emergency surgical procedures, and an increase in more severe septic surgical diseases, such as necrotic cholecystitis. It was probably due to to a critical delay in time-todiagnosis and time-to-intervention resulting to limited access to the operating theatres as well as intensive care units. Early laparoscopic cholecystectomy is the standard of care for acute cholecystitis. Moreover early data from COVID-19 pandemic reported an increase in the incidence of necrotic cholecystitis among COVID-19 patients. The ChoCO-W prospective observational collaborative study was conceived to investigate the incidence and management of acute cholecystitis under the COVID-19 pandemic.
\end{abstract}

Material and Methods: The present research protocol was. conceived and designed as a prospective observational international collaborative study focusing on the management of patients with to the diagnosis of acute cholecystitis under the COVID-19 pandemic. The study obtained the approval of the local Ethics Committee (Nimes, France) and meet and conform to the standards outlined in the Declaration of Helsinki. Eligible patients will be prospectively enrolled in the recruitment period and data entered in an online case report form.

Results: The ChoCO-W study will be the largest prospective study carried out during the first period of the COVID-19 pandemic with the aim to investigate the management of patients with acute cholecystitis, in the lack of studies focusing on COVID-19 positive patients.

Conclusion: The ChoCO-W study is conceived to be the largest prospective study to assess the management of patients presenting with acute cholecystitis during the COVID-19 pandemic and risk factors correlated with necrotic cholecystitis to improve the management of high-risk patients.

Keywords: Cholecystitis, management, COVID-19, SARS-CoV-2, WSES, ChoCO-W

Cite this article as: de Simone B, Catena F, Di Saverio S, Sartelli M, Abu-Zidan FM, Podda M, et al. Risk factors for necrotic cholecystitis during the COVID-19 pandemic: the ChoCO-WSES prospective collaborative study's experience. Turk J Surg 2021; 37 (4): 387-393.

Corresponding Author Belinda De Simone

E-mail: desimone.belinda@gmail.com

Received: 11.09 .2021

Accepted: 08.11.202

Available Online Date: 31.12 .2021

(0) Copyright 2021 by Turkish Surgical Society Available online at www.turkjsurg.com

DOI: $10.47717 /$ turkjsurg.2021.5507

\section{INTRODUCTION}

Acute cholecystitis (AC) is a common surgical disease for admission in the emergency department. Gangrenous cholecystitis (GC) is the most severe complication of AC, affecting around 15\% (range 2-30\%) of the patients in a emergency setting, which can progress in necrosis and perforation of the gallbladder and pericholecystic abscess, fistula with other organs such in the Mirizzi sindrome or generalised peritonitis (1).

GC is related to increased morbility and mortality rate (mortality rate ranging between 15 and 50\%) above all in elderly and high risk patients presenting with diabetes, coronary artery disease, and other chronic co-morbidities compared with non-necrotic $A C(2,3)$. 
Under the COVID-19 pandemic, several studies have reported an increased incidence of GC in COVID-19 positive patients and poor outcomes of patients managed non-operatively because of the limited access to operating theatres and intensive care units (4-7).

At present, the pathogenetic relationship of GC with COVID-19 infection is unknown, and the incidence of GC under this ongoing pandemic has not been defined and neither the risk factors correlated with developing this advanced form of acute cholecystitis.

Early laparoscopic cholecystectomy (LC) is the standard of care for AC, in COVID and non COVID patients. Tokyo Guidelines 2013 and its revised version in 2018 proposed a severity classification for AC to guide surgeons in non-operative or operative management of patients $(8,9)$, which is summarised in Table 1.

The World Society of Emergency Surgery (WSES) evidence-based guidelines more clearly recommended early LC in the management of patients with $A C$, remarking the importance of better distinguishing high-risk patients from patients non-suitable for surgery in considering non-operative management or postponing surgery (10).

To our knowledge, there are not clear criteria in selecting urgent surgical patients presenting acute cholecystitis patients for non operative and operative management apart from haemodynamic stability in decreasing life-threatening complications and mortality rate. During the COVID-19 pandemic, in the lack of practice recommendations, a multi-societary position paper has suggested considering percutaneous drainage of the gallbladder $(P C)$ after the failure of conservative therapy with antibiotics to delay surgical but treatment only in real conditions of the impracticability of a cholecystectomy (11).

With this collaborative study, we aim to prospectively study the effects of COVID-19 pandemic on clinical presentation, diagnosis, severity, and clinical outcome of acute cholecystitis globally to improve the management of high-risk patients that will not benefit from NOM, in non-COVID and in COVID patients.

In conclusion the "Risk Factors for necrotic Cholecystitis During the COVID-19 Pandemic" (ChoCO-W) study was conceived and supported by the World Society for Emergency Surgery (WSES) to:

-Assess the incidence of AC during COVID-19 pandemic;

-Investigate risk factors to develop GC under the COVID-19 pandemic;

-Evaluate the management of AC focusing on treatments and outcomes of operative and non-operative strategies in COVID-19 and non-COVID-19 patients to improve outcomes and decrease morbidity and mortality rates.

\section{MATERIAL and METHODS}

The ChoCO-W study was designed as a 12 month-period multicenter, observational, prospective cohort study with the purposes to:

1. Evaluate the incidence of AC during the COVID-19 pandemic;

2. Evaluate the risk factors for $\mathrm{GC}$;

\section{Table 1. Tokyo Guidelines 13/18 severity classification of cholecystitis}

\section{Grade III (severe) acute cholecystitis}

"Grade III" acute cholecystitis is associated with dysfunction of any one of the following organs/systems:

1. Cardiovascular dysfunction: hypotension requiring treatment with dopamine $\geq 5 \mu \mathrm{g} / \mathrm{kg}$ per min, or any dose of norepinephrine

2. Neurological dysfunction: decreased level of consciousness

3. Respiratory dysfunction: $\mathrm{PaO}_{2} / \mathrm{FiO}_{2}$ ratio $<300$

4. Renal dysfunction: oliguria, creatinine $>2.0 \mathrm{mg} / \mathrm{dl}$

5. Hepatic dysfunction: PT-INR $>1.5$

6. Hematological dysfunction: platelet count $<100,000 / \mathrm{mm}^{3}$

Grade II (moderate) acute cholecystitis

"Grade II" acute cholecystitis is associated with any one of the following conditions:

1. Elevated WBC count $\left(>18,000 / \mathrm{mm}^{3}\right)$

2. Palpable tender mass in the right upper abdominal quadrant

3. Duration of complaints $>72$ ha

4. Marked local inflammation (gangrenous cholecystitis, pericholecystic abscess, hepatic abscess, biliary peritonitis, emphysematous cholecystitis)

Grade I (mild) acute cholecystitis

"Grade I" acute cholecystitis does not meet the criteria of "Grade III" or "Grade II" acute cholecystitis. It can also be defined as acute cholecystitis in a healthy patient with no organ dysfunction and mild inflammatory changes in the gallbladder, making cholecystectomy a safe and low-risk operative procedure 
3. Assess the correlation between COVID-19 disease and necrotic cholecystitis;

4. Evaluate the management of acute cholecystitis according to the WSES international guidelines (2020) in terms of mortality and morbidity (6).

The draft of the first project was submitted for evaluation to a selected WSES steering committee of international acute care and mini-invasive surgeons for suggestions and comments.

Revisions were made, and the final protocol was approved and entered in the ClinicalTrials.gov register with the ID: NCT04542312.

The ChoCO-W study is an international collaborative study sponsored by the World Society of Emergency Surgery and supported by the Italian Society of Endoscopic Surgery (SICE).

It will be carried out between October 2020 and September 2021 in ChoCO-W participating centers, under the coordination of the unit of Emergency and Metabolic Minimally Invasive Surgery, at the Poissy and Saint Germain en Laye Group of Hospitals (France). Ethical approval was obtained from the Sud Mediterranee Ethics Committee, Nimes, France (2021.03.05 ter _ 21.01.16.09406) (supplemental material 1).

\section{The primary endpoint of the study is:}

- To assess the incidence of AC during the COVID-19 pandemic.

\section{Secondary endpoints of the study are:}

- To investigate the risk factors for GC in patients admitted with the diagnosis of acute cholecystitis and in the cohort of COVID-19 patients;

- to confirm the hypothesis that COVID-19 infection is a risk factor to present GC;

- $\quad$ to assess mortality rate due to GC during the COVID-19 pandemic;

- $\quad$ to assess the management of acute cholecystitis during the COVID-19 pandemic and the role of non-operative management strategy and operative management.

\section{Study Population}

This prospective multicenter observational study will be performed in various medical institutions over a 12-month period (October 2020-October 2021). All adult patients admitted to the surgical departments with a diagnosis of acute cholecystitis (with and without necrotising cholecystitis) will be prospectively enrolled in the study.

Patients with pancreatitis, primary peritonitis from cirrhosis, or ascites will not be included in the study.

\section{Inclusion Criteria}

Patients of all ages and sex admitted to the emergency department for acute cholecystitis, aged $\geq 18$ years.

\section{Exclusion Criteria}

Patients aged $<18$ years.

Patients presenting with biliary pancreatitis, cirrhosis or ascites will not be included in the database.

\section{Data Collection}

Every clinical centre, which will be asked to join the ChoCO-W study, will be identified by an ID number assigned by the principal investigator and the coordinator center before starting data collection. Each local ChoCO team research will be composed of one local investigator and two collaborators. An online case report form (supplemental material 2) by Google form platform will be available to collect data in a protected database: the link for accessing the online database will be sent to the local investigator and collaborators for anonymous online data entry. All epidemiological, clinical, surgical and follow up data will be collected in a six-month period. Only the principal investigator of the study will be able to access to the database totally anonymised and secured by a username and password.

\section{Sample Size Calculation}

The ChoCO-W study is an explorative one, and data will be used to assess the incidence of GC, to investigate risk factors for GC among patients admitted with the diagnosis of AC during the COVID-19 pandemic and their management in an emergency setting.

The sample size was calculated by considering the incidence of $\mathrm{GC}$ reported in the literature which corresponds to a range of $2-30 \%$. Taking into account the mean between the 2 values, and in the lack of data on the incidence of necrotic cholecystitis in COVID patients, that we assumed to be double the incidence of necrotic cholecystitis in the non-COVID population, with an alfa risk estimated error equal to 0.05, the study population will be composed of two cohorts of 111 patients.

\section{Statistical Analysis}

The present study aims to evaluate the incidence of GC among patients admitted for acute cholecystitis during COVID-19 pandemic. The statistician investigator will differentiate data by two cohorts of patients: non COVID and COVID patients and sex. The main aim of this study is to assess the management of all patients having severe acute cholecystitis during COVID-19 pandemic. Data will be analyzed in absolute frequency and percentage, in the case of qualitative variables. Quantitative variables were analysed as medians and interquartile range (IQR). Univariate analyses will be performed to study the association between 
risk factors and in-hospital mortality using a chi-square test, or a Fisher's exact test if the expected value of a cell was $<5$. All tests will be two-sided, and p values of 0.05 will be considered statistically significant. To investigate factors associated with death, a logistic regression model will be constructed, including variables with $p<0.05$ in the univariate analysis.

\section{Ethical Aspects}

The present study is an observational one and it will not attempt to change or modify the clinical practice of all participating investigators. All surgeons involved in patient recruitment will be responsible for local ethics committee approval, if required, the anonymous collection and data entry. The study will meet and conform to the standards outlined in the Declaration of Helsinki and Good Epidemiological Practices.

All surgeons involved in the patient recruitment will be included in the ChoCO-W research authorship.

\section{Informed Consent}

The present observational prospective study, with a retrospective analysis of data, will not attempt to change or modify clinical practices of the participating physicians, consequently, informed consent will not be required. Each eligible patient for this study will be informed about the study and will be asked to authorise the anonymous treatment of personal data, according to standard local clinical practice.

\section{Dissemination of Results and Publication Policy}

The primary statistical analysis of the study will be presented at the World Congress of the World Society of Emergency Surgery. The ChoCO-W study embraces corporate authorship and all collaborators that will contribute to this project will form the ChoCO-W collaborative group.

\section{Budget and Financing}

The study was conceived, designed and will be carried out without any academic or private fund.

\section{DISCUSSION}

$A C$ is one of the most common diseases of admission in the emergency department. The reported mortality of AC is approximately $3 \%$, but the rate increases with age or patients comorbidities. If appropriate treatment is delayed, life-threatening complications can develop as a consequence of management. GC is the worst manifestation of severe cholecystitis with increased morbidity and mortality rate above all for elderly and high comorbid patients.

The current standard of care in AC is an early LC with the appropriate administration of fluid, electrolyte, and antibiotics. What is unclear is how to recognise the group of patients that will develop GC associated to high operational risk to improve their management.
In the early phase of the ongoing COVID-19 pandemic, surgical activity was reorganised to allow caring about the enormous number of COVID patients needing admission in intensive care units for ventilatory support. Several authors have suggested considering non-operative strategies in the management of urgent surgical diseases in a period of limited access to operating theatres, lack of personal protective equipments and overwhelmed hospitals (12-14).

A multicenter retrospective-prospective cohort study about the management of acute cholecystitis in Madrid (Spain) (15) has shown an increase of non-surgical treatment of $A C$, and consequently an increase of conservative treatment failure, morbidity and hospital stay length, which may have led to an increased risk of hospital-acquired SARS-CoV-2 infection. Moreover, age, SARS-CoV-2 infection, AC severity and conservative treatment failure have been reported as mortality risk factors.

An Italian monocentric retrospective study (16) have reported data about 37 patients admitted with the diagnosis of $A C$ and the use of PC during COVID-19 pandemic. According to Tokyo Guidelines (2018), patients were successfully treated with antibiotics only, bedside PC and LC, in 29.7\%, 21.6\% and $48.7 \%$ of cases respectively. The overall success rate of percutaneous cholecystostomy was $87.5 \%$. Mean post-procedural hospitalization length was nine days. Median time of drainage removal was 43 days and only 50\% of patients thereafter underwent cholecystectomy.

Two other retrospective Turkish studies $(17,18)$ have respectively enrolled 72 and 36 patients and confirmed that PC can be an effective and safe alternative treatment for AC for delaying LC in COVID positive patients and selected negative ones and decreasing in-hospital diffusion of the infectious disease.

The ChoCO-W study could be the largest collaborative prospective study about AC carried out during the COVID-19 pandemic with a provisional number of 2000 patients enrolled with 42 countries involved (Table 2; Figure 1). The strength of the present study is the participation of surgical departments of all over the world and the effort made during the ongoing pandemic.

The limitation of the present study could be the retrospective analysis of data and the short follow up period of patients (period of hospitalisation).

\section{CONCLUSION}

AC is a common serious surgical disease. A group of patients will develop GC that is correlated with high morbidity and mortality rate. $L C$ is the standard of care. During the COVID-19 pandemic, surgical activity was re-organised to allow caring for critically ill COVID patients, and non-operative manage- 
Table 2. ChoCO-W involved countries

\begin{tabular}{|c|c|}
\hline Country & Count \\
\hline Albania & 5 \\
\hline Argentina & 1 \\
\hline Austria & 2 \\
\hline Belarus & 1 \\
\hline Bosnia and Herzegovina & 4 \\
\hline Brazil & 6 \\
\hline Bulgaria & 2 \\
\hline Colombia & 1 \\
\hline Croatia & 1 \\
\hline Egypt & 2 \\
\hline Ethiopia & 1 \\
\hline France & 4 \\
\hline Georgia & 1 \\
\hline Germany & 2 \\
\hline Greece & 22 \\
\hline India & 4 \\
\hline Indonesia & 1 \\
\hline Iran & 1 \\
\hline Israel & 1 \\
\hline Italy & 104 \\
\hline Japan & 1 \\
\hline Malaysia & 8 \\
\hline Mexico & 1 \\
\hline Pakistan & 2 \\
\hline Paraguay & 2 \\
\hline Poland & 4 \\
\hline Portugal & 1 \\
\hline Romania & 3 \\
\hline Russian Federation & 3 \\
\hline Serbia & 1 \\
\hline Singapore & 1 \\
\hline Slovakia & 1 \\
\hline Slovenia & 1 \\
\hline South Korea & 1 \\
\hline Spain & 10 \\
\hline Sudan & 1 \\
\hline Tunisia & 1 \\
\hline Turkey & 24 \\
\hline Ukraine & 3 \\
\hline United Arab Emirates & 5 \\
\hline United Kingdom & 11 \\
\hline USA & 2 \\
\hline
\end{tabular}

ment strategies were employed for delaying surgery, with high morbidity and increased length of hospital stay. Furthermore, COVID-19 disease seems to be correlated with the risk of presenting with GC.

The ChoCO-W study was conceived to assess the management of AC during the COVID-19 pandemic in COVID-19 and non-COVID-19 patients and to improve the management of patients presenting with GC to decrease morbidity and mortality rates especially in high risk and elderly patients.

\section{ACKNOWLEDGEMENTS}

The World Society of Emergency Surgery (WSES) and the Italian Society of Endoscopic Surgery (SICE) for having contributed to the diffusion of the study.

The ChoCO-W collaborative group for the collaboration and scientific contribution.

Many thanks to Professors Fausto Catena, Elie Chouillard and Andrew Gumbs.

Thanks to all ChoCO collaborators for their efforts during this pandemic

Ethics Committee Approval: This study approval was obtained from Sud Mediterranee Ethics Committee, Nimes, France (03.05.2021 21.01.16.09406)

Peer-review: Externally peer-reviewed.

Author Contributions: Concept - B.D.S.; Design - B.D.S, F.C.; F.M.A.Z.; Supervision - S.D.S., F.C., E.C., B.D.S, L.A., W.L.B., F.A.; Materials - B.D.S.; Data Collection and/or Processing - B.D.S.; Analysis and/or Interpretation - B.D.S., F.M.A.Z.; Literature Search - B.D.S.; Writing Manuscript - B.D.S.; Critical Reviews - All of authors.

Conflict of Interest: The authors have no conflicts of interest to declare.

Financial Disclosure: The authors declared that this study has received no financial support. 


\section{Timeline of the ChoCO-W protocol}

\section{July-August, 2020}

\section{September, 2020}

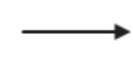

3.October, 2020

\section{July-August, 2021}

\author{
1.Conception, design and drafting of the ChoCO study \\ protocol
}

2.Presentation of the ChoCO project to the WSES board of directors for support and approval

3.Revision of the protocol according to suggestions of expert emergency and minimally invasive surgeons

1.The protocol is registered in ClinicalTrials.gov database

2.The process for ethical approval started and after several revisions and clarifications the protocol was definitively accepted in April, 2021

3.The online database was finalised and secured.

1.The diffusion of the study started and finally 234 international clinical centres decided to join the study

2.Selection and enrolment of patients in the online database started.

1. The enrolment of patients is definitely closed

\section{Data analysis started}

Figure 1. The ChoCO-W protocol timeline.

\section{REFERENCES}

1. Bourikian S, Anand RJ, Aboutanos M, Wolfe LG, Ferrada P. Risk factors for acute gangrenous cholecystitis in emergency general surgery patients. Am J Surg 2015; 210(4): 730-3. [CrossRef]

2. Önder A, Kapan M, Ülger BV, Oğuz A, Türkoğlu A, Uslukaya Ö. Gangrenous cholecystitis: mortality and risk factors. Int Surg 2015, 100(2): 254-60. [CrossRef]

3. Gomes CA, Soares C, Di Saverio S, Sartelli M, de Souza Silva PG, Orlandi AS, et al. Gangrenous cholecystitis in male patients: a study of prevalence and predictive risk factors. Ann Hepatobiliary Pancreat Surg 2019; 23(1): 34-40. [CrossRef]

4. Asti E, Lovece A, Bonavina L. Gangrenous cholecystitis during hospitalization for SARS-CoV2 infection. Updates Surg 2020; 72(3): 91719. [CrossRef]

5. Bruni A, Garofalo E, Zuccalà V, Currò G, Torti C, Navarra G, et al. Histopathological findings in a COVID-19 patient affected by ischemic gangrenous cholecystitis. World J Emerg Surg 2020; 15(1): 43. [CrossRef]

6. Alhassan SM, Iqbal P, Fikrey L, Mohamed Ibrahim MI, Qamar MS, Chaponda M, et al. Post COVID 19 acute acalculous cholecystitis raising the possibility of underlying dysregulated immune response, a case report. Ann Med Surg (Lond) 2020; 60: 434-7. [CrossRef]
7. Mattone E, Sofia M, Schembari E, Palumbo V, Bonaccorso R, Randazzo V, et al. Acute acalculous cholecystitis on a COVID-19 patient: a case report. Ann Med Surg (Lond) 2020; 58: 73-5. [CrossRef]

8. Yokoe M, Hata J, Takada T, Strasberg SM, Asbun HJ, Wakabayashi G, et al. Tokyo Guidelines 2018: diagnostic criteria and severity grading of acute cholecystitis (with videos). J Hepatobiliary Pancreat Sci 2018; 25(1): 41-54. [CrossRef]

9. Okamoto K, Suzuki K, Takada T, Strasberg SM, Asbun HJ, Endo I, et al. Tokyo Guidelines 2018: flowchart for the management of acute cholecystitis. J Hepatobiliary Pancreat Sci 2018; 25(1):55-72. [CrossRef]

10. Pisano M, Allievi N, Gurusamy K, Borzellino G, Cimbanassi S, Boerna D, et al. 2020 World Society of Emergency Surgery updated guidelines for the diagnosis and treatment of acute calculus cholecystitis. World J Emerg Surg 2020; 15(1): 61. [CrossRef]

11. Campanile FC, Podda M, Arezzo A, Botteri E, Sartori A, Guerrieri M, et al. Acute cholecystitis during COVID-19 pandemic: a multisocietary position statement. World J Emerg Surg 2020; 15(1): 38. [CrossRef]

12. Rickham PP. Human experimentation. Code of ethics of the world medical association. Declaration of Helsinki. Br Med J 1964; 2(5402): 177. [CrossRef]

13. de Simone B, Chouillard E, Di Saverio S, Pagani L, Sartelli M, Biffl WL, et al. Emergency surgery during the COVID-19 pandemic: what you need to know for practice. Ann R Coll Surg Engl 2020; 102(5): 323-2. [CrossRef] 
14. de Simone B, Chouillard E, Sartelli M, Biffl WL, Di Saverio S, Moore EE, et al. The management of surgical patients in the emergency setting during COVID-19 pandemic: the WSES position paper. World J Emerg Surg 2021; 16(1): 14. [CrossRef]

15. Martínez Caballero J, González González L, Rodríguez Cuéllar E, Ferrero Herrero E, Pérez Algar C, Vaello Jodra V, et al. Multicentre cohort study of acute cholecystitis management during the COVID-19 pandemic. Eur J Trauma Emerg Surg 2021; 47(3): 683-92. [CrossRef]

16. Barabino M, Piccolo G, Trizzino A, Fedele V, Ferrari C, Nicastro V, et al. COVID-19 outbreak and acute cholecystitis in a Hub Hospital in Milan: wider indications for percutaneous cholecystostomy. BMC Surg 2021;21(1): 180. [CrossRef]
17. Ciyiltepe H, Yıldırım G, Fersahoğlu MM, Aydın MT, Özcabı Y, Bulut $N E$, et al. Clinical approach to patients admitted to the emergency room due to acute cholecystitis during the COVID-19 pandemic and percutaneous cholecystostomy experience. Ulus Travma Acil Cerrahi Derg 2021; 27(1): 34-42. [CrossRef]

18. Somuncu E, Kara Y, Kızılkaya MC, Bozdağ E, Yıldız ZB, Özkan C, et al. Percutaneous cholecystostomy instead of laparoscopy to treat acute cholecystitis during the COVID-19 pandemic period: single center experience. Ulus Travma Acil Cerrahi Derg 2021; 27(1): 89-94. [CrossRef]

\section{ORIJINAL ÇALIŞMA-ÖZET}

Turk J Surg 2021; 37 (4): 387-393

\section{COVID-19 pandemisi süresince nekrotizan kolesistit risk faktörleri: ChoCO-WSES prospektif uluslararası çalışmasının deneyimi}

Belinda de Simone ${ }^{1}$, Fausto Catena ${ }^{2}$, Salomone Di Saverio ${ }^{3}$, Massimo Sartelli ${ }^{4}$, Fikri M. Abu-Zidan ${ }^{5}$, Mauro Podda ${ }^{6}$, Walter L Biffl ${ }^{7}$, Luca Ansaloni ${ }^{8}$, Federico Coccolini ${ }^{9}$, Ernest E Moore ${ }^{10}$, Yoram Kluger ${ }^{11}$, Carlos Augusto Gomes ${ }^{12}$, Ferdinando Agresta ${ }^{13}$, Elie Chouillard ${ }^{1}$

${ }^{1}$ Uluslararası de Poissy/Saint Germain En Laye Hastanesi, Acil ve Metabolik Minimal Invaziv CerrahiAnabilim Dalı, Poissy, Fransa

${ }^{2}$ Bufalini Travma Merkezi, Acil Cerrahi ve Travma Cerrahisi Anabilim Dalı, Cesene, Italya

${ }^{3}$ Genel Cerrahi Anabilim Dalı, Saint Mary of the Rescue, San Benedetto del Tronto, Italya

${ }^{4}$ Macerata Hastanesi, Genel Cerrahi Birimi, Macerata, Italya

${ }^{5}$ UAE Üniversitesi Tıp ve Sağlık Bilimleri Bölümü, Cerrahi Anabilim Dalı, Al-Ain, Arap Emirlikleri

${ }^{6}$ Cagliari Üniversite Hastanesi, Cerrahi Anabilim Dalı, Genel Cerrahi Birimi, Cagliari, Italya

${ }^{7}$ Scripps Memorial Hastanesi, Acil Cerrahi ve Travma Cerrahisi Anabilim Dalı, La Jolla-California, Amerika Birleşik Devletleri

${ }^{8}$ Pavia Üniversite Hastanesi, Genel Cerrahi Anabilim Dalı, Pavia, Italya

${ }^{9}$ Pisa Üniversite Hastanesi, Genel Cerrahi Anabilim Dalı, Pisa, İtalya

${ }^{10}$ Denver Health Medical, Ernest E Moore Şok Travma Merkezi, Amerika Birleşik Devletleri

${ }^{11}$ Rambam Sağlık Hizmetleri Kampüsü, Cerrahi Birimi, Haifa, İsrail

12 Juiz de Fora Üniversite Hastanesi, Cerrahi Anabilim Dalı, Juiz da Fora, Brezilya

${ }^{13}$ Adria Hastanesi, Genel Cerrahi Anabilim Dalı, Adria, Italya

\section{ÖZET}

Giriş ve Amaç: COVID-19 pandemisi süresince bazı çalışmalarda, acil cerrahi hastalarında azalma ve ameliyathane ve yoğun bakım ünitelerine sınırlı erişim sebebiyle tanıya kadar geçen sürenin ve müdahaleye kadar geçen sürenin uzaması nedenli nekrotizan kolesistit gibi daha ciddi septik hastalıklarda bir artış bildirilmiştir. Laparoskopik kolesistektomi, akut kolesistitin standart tedavi yöntemidir. Nekrotizan kolesistit ile başvuran hastaların yönetimi konusunda kesin öneriler bulunmamaktadır. Bu çalışmanın amacı, yüksek riskli hastaların yönetimlerini iyileştirmek için nekrotizan kolesistit insidansını değerlendirmek ve risk faktörlerini araştırmaktır.

Gereç ve Yöntem: Bu araştırma protokolü, akut kolesistit tanılı hastaların yönetimine odaklanan prospektif gözlemsel uluslararası ortak bir çalışma olarak tasarlanmıştır. Çalışma yerel etik kurul (Nimes, Fransa) onayı almış ve Helsinki Bildirgesinde istenilen standartlara uymaktadır. Uygun hastalar, çalışmaya hasta alımı esnasında prospektif olarak dahil edilecek ve veriler çevrimiçi olgu raporu formuna aktarılacaktır.

Bulgular: COVID-19 pandemisi süresince yüksek riskli hastalara odaklanan çalışmaların eksikliği sebebiyle ChoCO-W çalışması, akut kolesistitli hastaların yönetimini inceleyen en geniş prospektif çalışmadır.

Sonuç: ChoCO-W çalışmasının, COVID-19 pandemisi süresince yüksek riskli hastaların yönetimini iyileştimek amacıyla akut kolesistitli hastaların yönetimini ve nekrotizan kolesistit ile ilişkili risk faktörlerini değerlendiren en geniş prospektif çalışma olması tasarlanmıştır.

Anahtar Kelimeler: Kolesistit, yönetim, COVID-19, SARS-CoV-2, WSES, ChoCO-W

Doi: 10.47717/turkjsurg.2021.5507 